\title{
Molecular mechanisms of long non-coding RNAs in anaplastic thyroid cancer: a systematic review
}

\author{
Hilda Samimi ', Sayed Mahmoud Sajjadi-Jazi ${ }^{1,2}$, Soroush Seifirad ${ }^{3}$, Rasha Atlasi ${ }^{4}$, Habibollah Mahmoodzadeh ${ }^{5}$,
} Mohammad Ali Faghihi ${ }^{6,7}$ and Vahid Haghpanah ${ }^{1,8,9^{*}}$ (D)

\begin{abstract}
Background: anaplastic thyroid cancer (ATC) is one of the most lethal and aggressive cancers. Evidence has shown that the tumorigenesis of ATC is a multistep process involving the accumulation of genetic and epigenetic changes. Several studies have suggested that long non-coding RNAs (IncRNAs) may play an important role in the development and progression of ATC. In this article, we have collected the published reports about the role of IncRNAs in ATC.

Methods: "Scopus", "Web of Science,, "PubMed", "Embase", etc. were systematically searched for articles published since 1990 to 2020 in English language, using the predefined keywords.

Results: 961 papers were reviewed and finally 33 papers which fulfilled the inclusion and exclusion criteria were selected. Based on this systematic review, among a lot of evidences on examining the function of IncRNAs in thyroid cancer, there are only a small number of studies about the role of IncRNAs and their molecular mechanisms in the pathogenesis of ATC.

Conclusions: IncRNAs play a crucial role in regulation of different processes involved in the development and progression of ATC. Currently, just a few IncRNAs have been identified in ATC that may serve as prognosis markers such as GAS5, MIR22HG, and CASC2. Also, because of the dysregulation of KIhl14-AS, HOTAIRM1, and PCA3 during ATC development and progression, they may act as therapeutic targets. However, for most IncRNAs, only a single experiment has evaluated the expression profile in ATC tissues/cells. Therefore, further functional studies and expression profiling is needed to resolve this limitation and identify novel and valid biomarkers.
\end{abstract}

Keywords: Long non-coding RNA, Anaplastic thyroid cancer, Cancer stem cell, Systematic review, Tumor suppressor, Oncogene

\section{Background}

Thyroid cancer is the most frequent malignant neoplasm of the endocrine system [1]. Although the greater part of thyroid cancers have a good prognosis, some of these are correlated to further aggressive clinical manner [2]. Anaplastic thyroid cancer (ATC) is the most lethal and

\footnotetext{
*Correspondence: v.haghpanah@gmail.com; vhaghpanah@tums.ac.ir ${ }^{9}$ Endocrinology and Metabolism Research Center (EMRC), Dr. Shariati Hospital, North Kargar Ave., Tehran 14114, Iran

Full list of author information is available at the end of the article
}

aggressive thyroid cancer accounting $1-3 \%$ and its generally survival rate is just $3-6$ months following initial diagnosis [3].

In thyroid cancer, the majority of genetic alterations are directly associated with dysregulation of MAPK and PI3K/AKT signaling pathways for instance point mutations in $B R A F$ and $R A S$ genes, that have an important role in the modulation of cell growth, survival, and proliferation [4-6]. Also, epigenetic changes have a key role

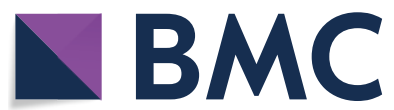

(c) The Author(s) 2020. This article is licensed under a Creative Commons Attribution 4.0 International License, which permits use, sharing, adaptation, distribution and reproduction in any medium or format, as long as you give appropriate credit to the original author(s) and the source, provide a link to the Creative Commons licence, and indicate if changes were made. The images or other third party material in this article are included in the article's Creative Commons licence, unless indicated otherwise in a credit line to the material. If material is not included in the article's Creative Commons licence and your intended use is not permitted by statutory regulation or exceeds the permitted use, you will need to obtain permission directly from the copyright holder. To view a copy of this licence, visit http://creativeco mmons.org/licenses/by/4.0/. The Creative Commons Public Domain Dedication waiver (http://creativecommons.org/publicdomain/ zero/1.0/) applies to the data made available in this article, unless otherwise stated in a credit line to the data. 
in the alterations of gene expression pattern in thyroid cancer [7].

In addition to genetic and epigenetic events, other biological mechanisms including non-coding RNAs (ncRNAs) play an important role in regulation of approximately all steps of cancer progression such as cell growth, epithelial to mesenchymal transition (EMT), and multidrug resistance (MDR) $[6,8]$. Based on their size, ncRNAs are usually classified as small ncRNAs incuding miRNAs, siRNAs, piRNAs, etc. and long non-coding RNAs (lncRNAs) with the length of longer than 200 nucleotides [8]. In contrast to small ncRNAs, lncRNAs are much less recognized relating to their roles in tumorigenesis and cancer progression, especially in ATC $[9,10]$.

In this article, we conducted a systematic review to evaluate the role of IncRNAs in ATC and discuss their molecular mechanisms in the pathogenesis of ATC and importance as potential diagnostic and prognostic biomarkers and therapeutic molecular targets for ATC.

\section{Method}

The main databases searched were "Scopus", "Web of Science (ISI)", "PubMed", and "Embase". Furthermore, to find more evidences, other sources such as "Google Scholar" were reviewed. The main search keywords were "long non-coding RNA", "noncoding RNA", "thyroid cancer" and "anaplastic thyroid cancer", and their logical combinations, related words and phrases, Medical Subject Headings (MeSH) terms, EBSCO thesaurus terms and Emtree terms. The search was restricted to the articles published in English language.

The inclusion criteria were studies which assessed the role of lncRNAs in thyroid cancer from 1990 to February 2020. The exclusion criteria were defined as articles which focused only on the role of IncRNAs in thyroid cancer other than ATC and non-English language studies. The titles and abstracts of articles were reviewed at once for the inclusion and exclusion criteria. In the next step, the full texts of the selected articles were re-evaluated to ensure they meet the eligibility criteria. Finally, to increase the comprehensiveness of the study, the reference lists of the selected articles were reviewed to identify other relevant studies.

\section{Results}

In the systematic search, 2076 published articles were identified. After removing the duplicates, 961 papers remained, which were reviewed by title/abstract and 851 articles were excluded because of irrelevant contents, lack of details, review articles and conference abstract as well as non-English papers. Finally, among the remaining 110 studies, 33 papers were found to fulfill the eligibility criteria by a full-text review and were selected for a systematic review. Figure 1 demonstrates the search flowchart of evidence acquisition according to the preferred reporting items for systematic reviews and meta-analyses (PRISMA) method. Based on our literature review, among a lot of evidences on examining the function of lncRNAs in thyroid cancer, there are only a small number of studies about the role of lncRNAs and their molecular mechanisms in the pathogenesis of ATC. All of the lncRNAs demonstrated to be involved in the development and progression of ATC are summarized in Table 1.

\section{Discussion}

Rising research indicates that lncRNAs have an important function in biology of thyroid cancers. Dysregulation of some lncRNAs is involved in thyroid tumorigenesis and its progression and can be important targets for molecular targeted therapy of thyroid cancers [43]. Although, the number of evidences on lncRNAs expression in thyroid cancer is growing, there are only a few studies about the role of lncRNAs and their molecular mechanisms on ATC. LncRNAs can act as tumor suppressor or oncogene by influencing important processes such as proliferation, invasion, metastasis, cell cycle, and apoptosis as well as cancer stem cell (CSC) properties during ATC tumorigenesis and progression (Tables 2, 3).

\section{Tumor suppressive IncRNAs in ATC}

CASC2 (cancer susceptibility candidate 2) is reported in several cancer types, acting as a tumor suppressor lncRNA with implications for diagnosis, therapy and prognosis. Upregulation of CASC2 decreased the cell proliferation of non-small cell lung cancer, representing that CASC2 can be a potential prognostic marker and therapeutic target in non-small cell lung cancer therapy [44]. Xiong et al. indicated that the low expression of CASC2 is correlated with multifocality and advanced tumor-node-metastasis (TNM) stage. Their findings showed that the expression of CASC2 can be an independent prognostic factor in thyroid cancer patients. In addition, upregulation of CASC2 decreased the proliferation and arrested cell cycle at $G_{0} / G_{1}$ phase in ATC cell lines [28]. Further studies are required to determine the CASC2 function as a potential prognostic marker and therapeutic target in ATC.

Guo et al.. demonstrated that GAS5 (Growth arrest special 5) expression is significantly decreased in ATC tissue samples in comparison to benign tissue samples. In this study, the expression of lncRNA GAS5 showed significant association with TNM staging, lymph node metastasis, and the several cancer foci of thyroid cancer. Therefore, GAS5 may be correlated with diagnosis and prognosis of thyroid cancer [12]. The molecular mechanism of cancer caused by downregulation of GAS5 still 


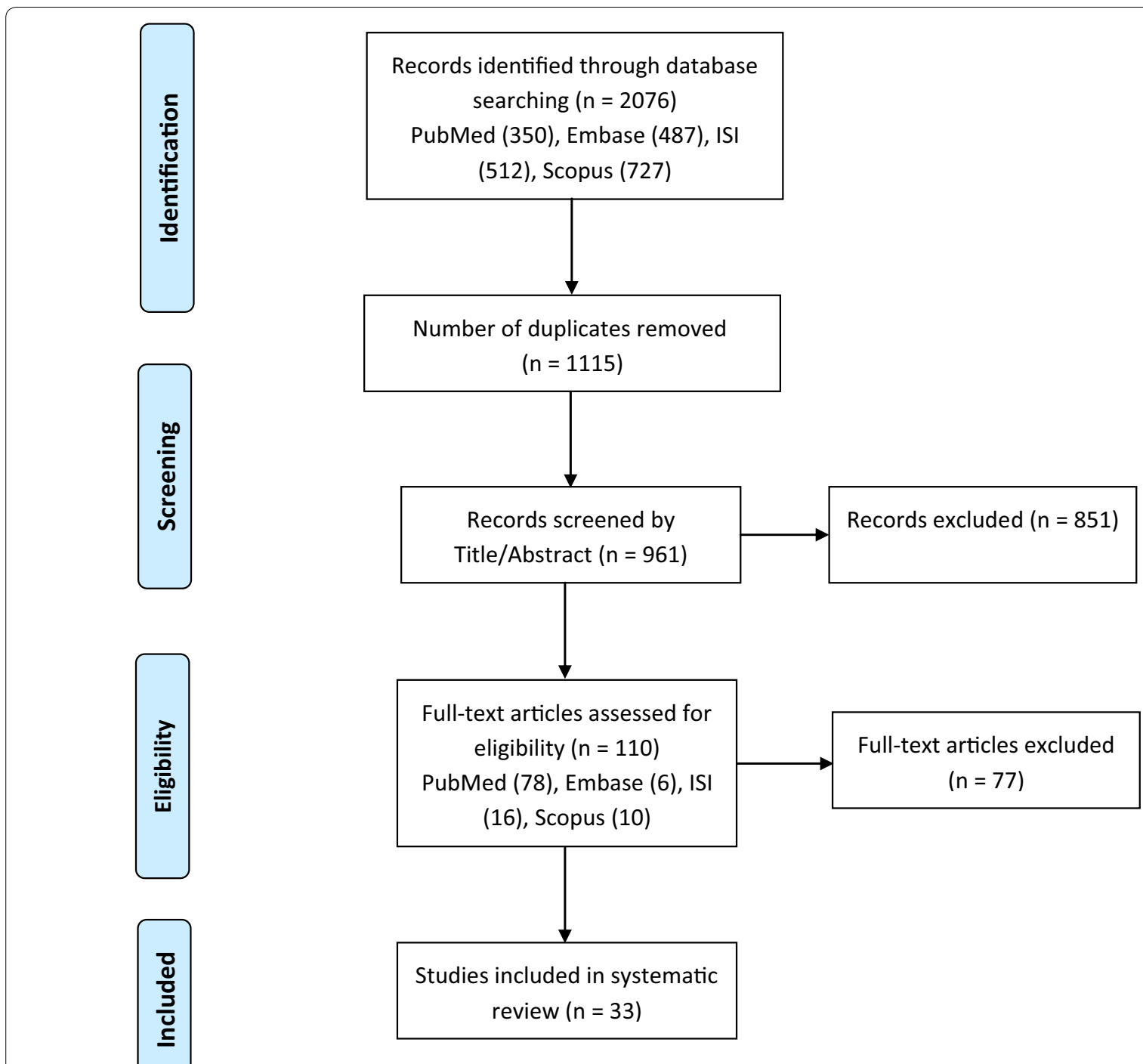

Fig. 1 Flowchart of the systematic review (PRISMA)

remains unknown. Downregulation of GAS5 probably increases the expression of cycling-dependent kinase 6 (CDK6) and consequently promotes cell cycle progression and proliferation [45].

The differentiation grade of neoplastic cells is a common evaluation of tumor malignancy, being lost in the advanced and aggressive types of thyroid cancer such as ATC. In thyroid cancer, the presence of differentiated cells is very important; because of their unique ability to concentrate iodine can be used for radioiodine therapy after surgery, to remove residual and/or metastatic cancer cells. ATC lack this differentiated function and therefore radioiodide therapy is not effective against it. Klhl14-AS (Kelch like family member 14) expression at early stages of thyroid development suggested a potential role in cellular and molecular mechanisms regulating cell differentiation and proliferation. Credendino and colleagues showed that the expression of Klhl14-AS is downregulated in different kinds of thyroid cancer, especially ATC tissues and cell lines. Downregulating Klhl14-AS expression in normal thyrocytes decreased the expression of thyroid differentiation markers and apoptosis and increased cell viability. These effects are mediated by the binding of Klhl14-AS to miR-182-5p and miR-20a-5p, which silenced PAX8 and BCL2, both important factors of thyroid differentiation and homeostasis [17]. Therefore, Klhl14-AS with potential tumor suppression activity may involve in thyroid differentiation and carcinogenesis and can be an effective target for ATC molecular therapy. 
Table 1 LncRNAs associated with ATC

\begin{tabular}{|c|c|c|c|c|c|c|c|}
\hline \multirow[t]{2}{*}{ Author/year } & \multirow[t]{2}{*}{ LncRNA } & \multirow{2}{*}{$\begin{array}{l}\text { Chromosomal } \\
\text { location }\end{array}$} & \multicolumn{2}{|l|}{ Sample } & \multirow[t]{2}{*}{ Expression } & \multirow[t]{2}{*}{ Summary of findings } & \multirow[t]{2}{*}{ Refs. } \\
\hline & & & $\begin{array}{l}\text { Cell line/ } \\
\text { tissue }\end{array}$ & Imor & & & \\
\hline $\mathrm{Kim} / 2016$ & LOC100507661 & $3 q 26.2$ & $\begin{array}{l}C 643 \\
8505 C\end{array}$ & - & Up & $\uparrow$ Cell proliferation, migration, and invasion ${ }^{a}$ & {$[11]$} \\
\hline $\mathrm{Gu} / 2017$ & GAS5 & $1 \mathrm{q} 25.1$ & - & 33 & Down & $\begin{array}{l}\uparrow \text { Cell cycle progression and proliferation probably by upregulating } \\
\text { of CDK6 } \\
\downarrow \text { Survival rate } \\
\text { Poor prognosis }\end{array}$ & {$[12]$} \\
\hline Zhang/2019 & $\mathrm{H} 19$ & $11 \mathrm{p} 15.5$ & $\begin{array}{l}8505 C \\
\text { SW1736 } \\
\text { KAT18 } \\
\text { CAL62 }\end{array}$ & 19 & Up & $\begin{array}{l}\uparrow \text { Proliferation, migration, and invasion } \\
\downarrow \text { Apoptosis }\end{array}$ & {$[13]$} \\
\hline Wang/2018 & UCA1 & 19p13.12 & $\begin{array}{l}\text { SW1736 } \\
\text { KAT18 }\end{array}$ & 8 & Up & $\begin{array}{l}\uparrow \text { cell viability, proliferation, migration, and invasion via binding to } \\
\text { miR-135a and regulation of c-myc expression }\end{array}$ & {$[14]$} \\
\hline Wang/2019 & HOTAIRM1 & 7p15.2 & - & 10 & Up & $\begin{array}{l}\uparrow \text { HOTAIRM } 1 \text { expression during thyroid cancer development and } \\
\text { progression }\end{array}$ & [15] \\
\hline Wang/2019 & PCA3 & $9 q 21.2$ & - & 10 & Up & $\begin{array}{l}\uparrow \text { PCA3 expression during thyroid cancer development and progres- } \\
\text { sion }\end{array}$ & {$[15]$} \\
\hline Chen/2019 & HCP5 & $6 p 21.33$ & $\begin{array}{l}\text { SW1736 } \\
8305 C \\
\text { ARO } \\
\text { FRO }\end{array}$ & 19 & Up & $\begin{array}{l}\uparrow \text { Cell viability and } \\
\downarrow \text { Apoptosis by regulating the expression of miR-128-3p }\end{array}$ & {$[16]$} \\
\hline Credendino/2019 & $\begin{array}{l}\text { KLHL14-AS } \\
(\mathrm{Klhl} 14)^{c}\end{array}$ & $18 q 12.1$ & $\begin{array}{l}8505 C \\
\text { CAL62 }\end{array}$ & 9 & Down & $\begin{array}{l}\uparrow \text { Cell viability and } \\
\downarrow \text { Cpoptosis and differentiation by binding to miR-182-5p and miR- } \\
20 \text { a-5p and regulation of BCL2 and PAX8 expression }\end{array}$ & [17] \\
\hline Du/2018 & Linc00210 & $1 \mathrm{q} 41$ & $8505 C$ & $\mathrm{~N} / \mathrm{A}$ & Up & $\begin{array}{l}\uparrow \text { Proliferation, migration, and invasion via binding to miR-195-5p and } \\
\text { upregulation of IGF1R expression }\end{array}$ & [18] \\
\hline $\mathrm{Hou} / 2018$ & TNRC6C-AS1 & $17 q 25.3$ & $\begin{array}{l}\text { ARO } \\
\mathrm{Hth} 74\end{array}$ & N/A & Up & $\begin{array}{l}\uparrow \text { Proliferation, migration, and invasion via binding to miR-129-5p and } \\
\text { upregulation of UNC5B expression }\end{array}$ & {$[19]$} \\
\hline $\mathrm{Li} / 2017$ & AK139328 & N/A & $8505 C$ & N/A & Up & $\uparrow$ Cell viability, invasion, and cell cycle progression & {$[20]$} \\
\hline Song/2017 & LINC00312 & $3 p 25.3$ & $8505 C$ & 13 & Down & $\begin{array}{l}\uparrow \text { Proliferation, invasion, and migration by regulating of miR-197-3p } \\
\text { expression and its target p120 }\end{array}$ & {$[21]$} \\
\hline Min/2018 & & & $8505 C$ & N/A & Down & $\begin{array}{l}\uparrow \text { Proliferation and invasion by suppressing PI3K/AKT signaling } \\
\text { pathway }\end{array}$ & {$[22]$} \\
\hline Liu/2018 & XIST & $\mathrm{Xq13.2}$ & $\begin{array}{l}\text { SW1736 } \\
\text { KAT18 }\end{array}$ & - & Up & $\begin{array}{l}\uparrow \text { Proliferation through binding to miR-34a and upregulation of MET } \\
\text { expression } \\
\uparrow \text { MET/PI3K/AKT signaling pathway }\end{array}$ & [23] \\
\hline Chen/2019 & SNHG7 & $9 q 34.3$ & CAL62 & N/A & Up & $\uparrow$ Proliferation and cell cycle progression & {$[24]$} \\
\hline $\mathrm{Liu} / 2018$ & SNHG15 & $7 p 13$ & $8505 C$ & N/A & Down & $\uparrow$ Proliferation, migration, and invasion via upregulating miR-510-5p & {$[25]$} \\
\hline $\mathrm{Han} / 2019$ & ZFAS1 & $20 q 13.13$ & CAL62 & 20 & Up & $\uparrow$ Proliferation and cell cycle progression & {$[26]$} \\
\hline Qin/2019 & MIR22HG & $17 p 13.3$ & - & 11 & Down & $\begin{array}{l}\downarrow \text { MIR22HG is correlated to higher age, lymph node metastasis, and } \\
\text { advanced TNM stages } \\
\uparrow \text { MIR22HG expression is associated with longer overall and disease- } \\
\text { free survival time in thyroid cancer patients. }\end{array}$ & {$[27]$} \\
\hline Xiong/2017 & CASC2 & $10 q 26.11$ & $\begin{array}{l}8505 \mathrm{C} \\
\text { CAL62 } \\
\text { HTH-83 }\end{array}$ & N/A & Down & $\begin{array}{l}\text { ? } \downarrow \text { CASC2 expression is correlated with multifocality and advanced } \\
\text { TNM stages } \\
\uparrow \text { CASC2 expression decreases the proliferation and arrests cell cycle } \\
\text { at } G_{0} / G_{1}\end{array}$ & {$[28]$} \\
\hline Yan/2019 & NEAT1 & $11 q 13.1$ & $\begin{array}{l}8505 C \\
\text { SW1736 }\end{array}$ & 26 & Up & $\downarrow$ Cisplatin-resistance through regulating of miR-9-5p/SPAG9 axis & [29] \\
\hline \multicolumn{8}{|c|}{ LncRNAs related to CSCs properties $^{d}$} \\
\hline Hardin/2018 & ROR & $18 q 21.31$ & THJ-16T & - & Up & $\begin{array}{l}\uparrow \text { CSC properties probably by modulating of OCT4, SOX2, and Nanog } \\
\text { expression } \\
\uparrow \text { ROR expression in CSC clones of ATC line THJ-16T compared to the } \\
\text { parental line } \\
\uparrow \text { Stem cell marker SOX2 and EMT marker SLUG }\end{array}$ & {$[30]$} \\
\hline
\end{tabular}


Table 1 (continued)

\begin{tabular}{|c|c|c|c|c|c|c|c|}
\hline \multirow[t]{2}{*}{ Author/year } & \multirow[t]{2}{*}{ LncRNA } & \multirow{2}{*}{$\begin{array}{l}\text { Chromosomal } \\
\text { location }\end{array}$} & \multicolumn{2}{|l|}{ Sample } & \multirow[t]{2}{*}{ Expression } & \multirow[t]{2}{*}{ Summary of findings } & \multirow[t]{2}{*}{ Refs } \\
\hline & & & $\begin{array}{l}\text { Cell line/ } \\
\text { tissue }\end{array}$ & imor & & & \\
\hline Zhou/2016 & PVT1 & $8 q 24.21$ & $8505 C$ & 7 & Up & $\begin{array}{l}\uparrow \text { Cell cycle progression and proliferation by modulating of cyclin D1 } \\
\text { and TSHR expression and also EZH2 recruitment }\end{array}$ & [31] \\
\hline Hardin/2018 & & & $\mathrm{THJ}-16 \mathrm{~T}$ & - & Down & $\begin{array}{l}\downarrow \text { PVT1 expression in CSC clones of ATC line THJ-16T compared to the } \\
\text { parental line } \\
\uparrow \text { Stem cell marker SOX2 and EMT marker SLUG }\end{array}$ & {$[30]$} \\
\hline Hardin/2018 & HOTAIR & $12 q 13.13$ & $\mathrm{THJ}-16 \mathrm{~T}$ & - & Down & $\begin{array}{l}\downarrow \text { HOTAIR expression in CSC clones of ATC line THJ-16T compared to } \\
\text { the parental line } \\
\uparrow \text { Stem cell marker SOX2 and EMT marker SLUG }\end{array}$ & {$[30]$} \\
\hline Huang/2016 & & & $\begin{array}{l}\text { SW1736 } \\
\text { KAT18 }\end{array}$ & - & UP & $\uparrow$ Proliferation and invasion via upregulating of IQGAP1 expression & {$[32]$} \\
\hline Zhang/2017 & & & - & 35 & Down & $\downarrow$ MALAT1 expression in ATC tissue samples & [33] \\
\hline Samimi/2019 & MALAT1 & $11 q 13.1$ & $\begin{array}{l}\text { SW1736 } \\
\text { C643 }\end{array}$ & - & Up & $\begin{array}{l}\uparrow \text { Mcl1 and cyclin D1 expression } \\
\downarrow \text { miR-363-3p expression }\end{array}$ & [34] \\
\hline Gou/2019 & & & $\begin{array}{l}\text { SW1736 } \\
8505 C\end{array}$ & - & Up & $\begin{array}{l}\uparrow \text { Proliferation, migration, and invasion } \\
\downarrow \text { Apoptosis and autophagy via binding to miR-200a-3p and upregu- } \\
\quad \text { lation of FOXA1 expression }\end{array}$ & {$[35]$} \\
\hline Hardin/2018 & & & THJ-16T & - & Up & $\begin{array}{l}\uparrow \text { MALAT1 expression in CSC clones of ATC cell line compared to the } \\
\text { parental line } \\
\uparrow \text { Stem cell marker SOX2 and EMT marker SLUG }\end{array}$ & [30] \\
\hline $\mathrm{Liu} / 2017$ & BANCR & $9 q 21.12$ & $8505 C$ & - & Up & $\begin{array}{l}\uparrow \text { Cell growth, colony formation ability, and cell cycle progression via } \\
\text { regulating of BANCR/TSHR/CCND1 signaling pathway }\end{array}$ & [36] \\
\hline $\mathrm{Liu} / 2019$ & FOXD2-AS1 & $1 p 33$ & $\begin{array}{l}8305 C \\
\text { CAL62 } \\
\text { BHT101 }\end{array}$ & 10 & Up & $\begin{array}{l}\uparrow \text { FOXD2-AS1 expression in cell lines and tissues } \\
\text { FOXD2-AS1 acts as a ceRNA for miR-7-5p and upregulates TERT } \\
\text { expression, which increases the CSCs properties in thyroid cancer } \\
\text { cells }\end{array}$ & [37] \\
\hline Wang/2018 & PTCSC3 & $14 q 13.3$ & $8505 C$ & 20 & Down & $\begin{array}{l}\uparrow \text { CSC properties by upregulating of STAT3, INO } 80, C^{133} \text {, and ALDH1 } \\
\uparrow \text { Drug resistance by upregulating of MDR- } 1 \text { via STAT3/INO80 pathway }\end{array}$ & [38] \\
\hline Fan/2013 & & & $8505 C$ & - & Down & $\begin{array}{l}\downarrow \text { Apoptosis } \\
\uparrow \text { Cell growth and cell cycle progression probably by modulating of } \\
\quad \text { miR-574-5p }\end{array}$ & [39] \\
\hline Lu/2018 & MANCR & 10p15.1 & BHT101 & - & Up & $\begin{array}{l}\downarrow \text { Apoptosis } \\
\uparrow \text { Proliferation, colony formation, cell cycle progression } \mathrm{G}_{0} \text { to } \mathrm{G}_{1} \text {, and } \\
\text { EMT by modulating E-cadherin, } \mathrm{N} \text {-cadherin, and } \beta \text {-catenin expres- } \\
\text { sion }\end{array}$ & {$[40]$} \\
\hline Pellecchia/2020 & PAR5 & $15 q 11.2$ & $\begin{array}{l}8505 C \\
\text { ACT1 } \\
\text { FB-1 } \\
\text { FRO }\end{array}$ & 9 & Down & $\begin{array}{l}\uparrow \text { Proliferation, colony formation, and EMT through regulating EZH2 } \\
\text { recruitment and E-cadherin expression }\end{array}$ & [41] \\
\hline Lei/2017 & TUG1 & $22 q 12.2$ & $\begin{array}{l}\text { SW1736 } \\
\text { KAT18 }\end{array}$ & N/A & Up & $\begin{array}{l}\uparrow \text { Proliferation, colony formation, invasion, migration, and EMT } \\
\text { through regulating miR-145/ZEB1 signaling pathway }\end{array}$ & {$[42]$} \\
\hline
\end{tabular}

AKT, AKT serine/threonine kinase; ALDH1, aldehyde dehydrogenase 1; BANCR, BRAF-activated non-protein coding RNA; BCL2, BCL2 apoptosis regulator; CASC2, cancer susceptibility candidate 2; CCND1, cyclin D1; CDK6, cycling-dependent kinase 6; ceRNA, competing endogenous RNA; C-myc, avian myeocytomatosis virus oncogene cellular homolog; CSC, cancer stem cell; EMT, epithelial to mesenchymal transition; EZH2, enhancer of zeste homolog 2; FOXA1, forkhead box protein A1; FOXD2-AS1, FOXD2 adjacent opposite strand RNA 1; GAS5, growth arrest special 5; HCP5, HLA complex P5; HOTAIR, HOX transcript antisense RNA; HOTAIRM1, hox antisense intergenic RNA myeloid 1; IGF1R, insulin like growth factor 1 receptor; INO80, INO80 complex ATPase subunit; IQGAP1, Ras GTPase-activating-like protein; KIhl14, kelch like family member 14; Linc00210, long intergenic non-protein coding RNA 210; LINC00312, long intergenic non-protein coding RNA 312; LnCRNA, long noncoding RNA, MALAT1: metastasis-associated lung adenocarcinoma transcript 1; MANCR, mitotically associated long non coding RNA; Mcl1, myeloid cell leukemia 1; MDR-1, multidrug resistance protein 1; MET, MET protooncogene; miR, microRNA; MIR22HG, MIR22 host gene; NEAT1, nuclear paraspeckle assembly transcript 1; OCT4, octamer-binding transcription factor 4; PAR5, Prader Wili/Angelman region RNA 5; PAX8, paired box 1; PCA3, prostate cancer antigen 3; PI3K, phosphatidylinositol-3-kinas; PTCSC3, papillary thyroid carcinoma susceptibility candidate 3; PVT1, plasmacytoma variant translocation 1; ROR, regulator of reprogramming; SNHG15, small nucleolar RNA host gene 15; SNHG7, small nucleolar RNA host gene 7; SOX2, SRY-box transcription factor 2; SPAG9, sperm associated antigene 9; STAT3, signal transducer and activator of transcription 3; TNM, tumor-node-metastasis; TNRC6C-AS1, TNRC6C antisense RNA 1; TUG1, taurine up-regulated gene 1; UCA1, urothelial carcinoma-associated 1; UNC5B, unc-5 netrin receptor B; XIST, X inactive specific transcript; ZEB1, zinc finger E-box binding homeobox 1; ZFAS1, ZNFX1 antisense RNA 1

a $\uparrow$ Increase

$b \downarrow$ Decrease

c In GeneCards database is named Klhl14

d Based on the criteria defined in the text 
Table 2 LncRNAs and their roles in ATC

\begin{tabular}{|c|c|c|c|}
\hline LncRNA & $\begin{array}{l}\text { Tumor } \\
\text { suppressor }\end{array}$ & Oncogene & CSC properties \\
\hline AK139328 & - & + & N/D \\
\hline BANCR & - & + & + \\
\hline CASC2 & + & - & N/D \\
\hline FOXD2-AS1 & - & + & + \\
\hline GAS5 & + & - & N/D \\
\hline H19 & - & + & N/D \\
\hline HCP5 & - & + & N/D \\
\hline HOTAIR & + & - & + \\
\hline HOTAIRM1 & - & + & N/D \\
\hline KLHL14-AS & + & - & N/D \\
\hline Linc00210 & - & + & N/D \\
\hline LINC00312 & + & - & N/D \\
\hline LOC100507661 & - & + & N/D \\
\hline MALAT1 & - & + & + \\
\hline MANCR & - & + & + \\
\hline MIR22HG & + & - & N/D \\
\hline NEAT1 & - & + & N/D \\
\hline PAR5 & + & - & + \\
\hline PCA3 & - & + & N/D \\
\hline PTCSC3 & + & - & + \\
\hline PVT1 & - & + & + \\
\hline $\mathrm{ROR}$ & - & + & + \\
\hline SNHG15 & + & - & N/D \\
\hline SNHG7 & - & + & N/D \\
\hline TNRC6C-AS1 & - & + & N/D \\
\hline TUG1 & - & + & + \\
\hline UCA1 & - & + & N/D \\
\hline XIST & - & + & N/D \\
\hline ZFAS1 & - & + & $N / D$ \\
\hline
\end{tabular}

$\mathrm{N} / \mathrm{D}$, not detected; BANCR, BRAF-activated non-protein coding RNA; CASC2, cancer susceptibility candidate 2; CSC, cancer stem cell; FOXD2-AS1, FOXD2 adjacent opposite strand RNA 1; GAS5, growth arrest special 5; HCP5, HLA complex P5; HOTAIR, HOX transcript antisense RNA; HOTAIRM1, hox antisense intergenic RNA myeloid 1; Klhl14, kelch like family member 14; Linc00210, long intergenic non-protein coding RNA 210; LINC00312, long intergenic non-protein coding RNA 312; LncRNA, long noncoding RNA, MALAT1: metastasis-associated lung adenocarcinoma transcript 1 ; MANCR, mitotically associated long non coding RNA; MIR22HG, MIR22 host gene; NEAT1, nuclear paraspeckle assembly transcript 1; PAR5, Prader Wili/Angelman region RNA 5; PCA3, prostate cancer antigen 3; PTCSC3, papillary thyroid carcinoma susceptibility candidate 3; PVT1, plasmacytoma variant translocation 1; ROR, regulator of reprogramming SNHG15, small nucleolar RNA host gene 15; SNHG7, small nucleolar RNA host gene 7; TNRC6C-AS1, TNRC6C antisense RNA 1; TUG1, taurine up-regulated gene 1;UCA1, urothelial carcinoma-associated 1; XIST, X inactive specific transcript; ZFAS1, ZNFX1 antisense RNA 1

Song et al.. indicated that thyroid cancer tissues including ATC samples have a lower expression of LINC00312 (long intergenic non-protein coding RNA 312), also known as NAG7, than adjacent normal tissues. Low expression of LINC00312 was found in patients with larger tumor, lymphatic metastasis, and advanced TNM stages (III and IV). Conversely, miR-197-3p is highly expressed in patients with such clinicopathological characteristics. Their findings demonstrated that LINC00312 overexpression could reduce the proliferation, migration, and invasion of ATC cell line by regulating the expression of miR-197-3p and its target p120 [21]. Evidences showed that miR-197 directly targets 120 through binding to the 3'UTR of p120 mRNA. Also, decreased p120 expression is associated with an increased risk of cancer cell migration and invasion via its impact on cadherin stability and turnover [46, 47]. In ovarian and pancreatic cancer cells, increased expression of miR-197-3p induces invasion and migration [46, 48]. In another study, Min and colleagues showed that LINC00312 expression is decreased in ATC cell line compared with normal thyroid follicular epithelial cells. LINC00312 knockdown with siRNA increased the proliferation and invasion of ATC cell line. Conversely, overexpression of LINC00312 decreased cell proliferation and invasion in vitro, and tumorigenicity in vivo. LINC00312-mediated tumor suppression in ATC cells may occur through suppression of PI3K/AKT signaling pathway and MMP9 gene expression [22]. Among the matrix metalloproteinases, MMP-9 has an important role not only in extracellular matrix degradation during tissue remodeling, but also in pathological processes such as invasion and metastasis of tumor cells and overexpresses in thyroid cancer cells [49-51].

MIR22HG (MIR22 host gene) is a tumor suppressor lncRNA involved in proliferation and progression of several types of cancer such as lung cancer. MIR22HG is downregulated and associated with patient survival in lung cancer. Decreased MIR22HG expression is associated with increased expression levels of MET and p21 oncogenes and cancer cell survival via its impact on YBX1 protein stability [52]. Qin and colleagues showed that MIR22HG is downregulated in thyroid cancer including ATC tissues by analyzing TCGA database. They found that the lower expression levels of MIR22HG is correlated to higher age, lymph node metastasis, and advanced TNM stages as well as higher MIR22HG expression is associated with longer overall and disease-free survival time in thyroid cancer patients. Bioinformatics analysis indicated that MIR22HG is involved in apoptosis and cell cycle processes, transcription and mRNA splicing regulation as well as and Hippo signaling pathway in thyroid cancer [27].

Recent findings have shown that SNHG15 (Small nucleolar RNA host gene 15) is involved in proliferation, migration, and invasion of thyroid cancer and correlated with age, clinicopathological characteristics, and disease-free survival [53]. Liu et al.. showed that there is a negative association between the expression of SNHG15 and miR-510-5p expression in ATC cell line. In addition, 
Table 3 The possible mechanisms of IncRNAs in ATC

\begin{tabular}{|c|c|c|c|c|c|c|c|c|}
\hline \multirow[t]{2}{*}{ LncRNA } & \multirow{2}{*}{$\begin{array}{l}\text { Cell proliferation/ } \\
\text { viability/growth }\end{array}$} & \multirow[t]{2}{*}{ Cell cycle } & \multirow[t]{2}{*}{ Invasion } & \multicolumn{5}{|c|}{ Cellular function } \\
\hline & & & & Migration & Apoptosis & Differentiation & Autophagy & CSC properties \\
\hline LOC100507661 & $\sqrt{ }$ & & $\sqrt{ }$ & $\sqrt{ }$ & & & & \\
\hline GAS5 & $\sqrt{ }$ & $\sqrt{ }$ & & & & & & \\
\hline $\mathrm{H} 19$ & $\sqrt{ }$ & & $\sqrt{ }$ & $\sqrt{ }$ & $\sqrt{ }$ & & & \\
\hline UCA1 & $\sqrt{ }$ & & $\sqrt{ }$ & $\sqrt{ }$ & & & & \\
\hline HCP5 & $\sqrt{ }$ & & & & $\sqrt{ }$ & & & \\
\hline KLHL14-AS & $\sqrt{ }$ & & & & $\sqrt{ }$ & $\sqrt{ }$ & & \\
\hline Linc00210 & $\sqrt{ }$ & & $\sqrt{ }$ & & & & & \\
\hline TNRC6C-AS1 & $\sqrt{ }$ & & $\sqrt{ }$ & $\sqrt{ }$ & & & & \\
\hline AK139328 & $\sqrt{ }$ & $\sqrt{ }$ & $\sqrt{ }$ & & & & & \\
\hline LINC00312 & $\sqrt{ }$ & & $\sqrt{ }$ & $\sqrt{ }$ & & & & \\
\hline XIST & $\sqrt{ }$ & & & & & & & \\
\hline SNHG7 & $\sqrt{ }$ & $\sqrt{ }$ & & & & & & \\
\hline SNHG15 & $\sqrt{ }$ & & $\sqrt{ }$ & $\sqrt{ }$ & & & & \\
\hline ZFAS1 & $\sqrt{ }$ & $\sqrt{ }$ & & & & & & \\
\hline CASC2 & $\sqrt{ }$ & $\sqrt{ }$ & & & & & & \\
\hline ROR & & & & & & & & $\sqrt{ }$ \\
\hline PVT1 & $\sqrt{ }$ & $\sqrt{ }$ & & & & & & $\sqrt{ }$ \\
\hline HOTAIR & & & & & & & & $\sqrt{ }$ \\
\hline MALAT1 & $\sqrt{ }$ & & $\sqrt{ }$ & $\sqrt{ }$ & $\sqrt{ }$ & & $\sqrt{ }$ & $\sqrt{ }$ \\
\hline BANCR & $\sqrt{ }$ & $\sqrt{ }$ & & & & & & $\sqrt{ }$ \\
\hline FOXD2-AS1 & & & & & & & & $\sqrt{ }$ \\
\hline PTCSC3 & $\sqrt{ }$ & $\sqrt{ }$ & & & $\sqrt{ }$ & & & $\sqrt{ }$ \\
\hline MANCR & $\sqrt{ }$ & $\sqrt{ }$ & & & $\sqrt{ }$ & & & $\sqrt{ }$ \\
\hline PAR5 & $\sqrt{ }$ & & & & & & & $\sqrt{ }$ \\
\hline TUG1 & $\sqrt{ }$ & & $\sqrt{ }$ & $\sqrt{ }$ & & & & $\sqrt{ }$ \\
\hline
\end{tabular}

IncRNAs such as MIR22HG, HOTAIRM1, and PCA3 are involved in the development, progression, and prognosis of ATC, their function in different cellular processes have not yet been determined

BANCR, BRAF-activated non-protein coding RNA; CASC2, cancer susceptibility candidate 2; CSC, cancer stem cell; FOXD2-AS1, FOXD2 adjacent opposite strand RNA 1; GAS5, growth arrest special 5; HCP5, HLA complex P5; HOTAIR, HOX transcript antisense RNA; KIhl14, kelch like family member 14; Linc00210, long intergenic non-protein coding RNA 210; LINC00312, long intergenic non-protein coding RNA 312; LncRNA, long noncoding RNA, MALAT1: metastasis-associated lung adenocarcinoma transcript 1; MANCR, mitotically associated long non coding RNA; PAR5, Prader Wili/Angelman region RNA 5; PTCSC3, papillary thyroid carcinoma susceptibility candidate 3; PVT1, plasmacytoma variant translocation 1; ROR, regulator of reprogramming; SNHG15, small nucleolar RNA host gene 15; SNHG7, small nucleolar RNA host gene 7; TNRC6C-AS1, TNRC6C antisense RNA 1; TUG1, taurine up-regulated gene 1; UCA1, urothelial carcinoma-associated 1; XIST, X inactive specific transcript; ZFAS1, ZNFX1 antisense RNA 1

miR-510-5p increased ATC cell line proliferation, migration, and invasion through downregulating SNHG15 [25].

\section{Oncogenic IncRNAs in ATC}

Kim and colleagues indicated that LOC100507661 expression is significantly increased in thyroid cancer tissues compared to paired adjacent normal tissues and suggested that it probably serves as an oncogene in thyroid cancers [11]. Furthermore, they showed that the expression level of LOC100507661 is higher in papillary thyroid cancer (PTC) and ATC cell lines with metastasis to lymph node or $B R A F^{\mathrm{V} 600 \mathrm{E}}$ mutation [11]. They also revealed that vector-mediated overexpression of LOC100507661 in ATC cells induced cell proliferation, migration, and invasion [11]. Currently, there is no information about the functional mechanisms of LOC100507661. However, because of the lower expression level in thyroid than in other tissues and higher expression level in fetal thyroid it may play an important role in thyroid development and tumorigenesis [11].

Evidences have shown that $\mathrm{H} 19$ can function either as a tumor suppressor or as a tumor promoter, depending on the type, stage, and genetic background of cancer cells. Zhang et al. showed that H19 is upregulated in ATC tissues. In this study, targeted inhibition of H19 with siRNA decreased proliferation, migration, and invasion and increased apoptosis in ATC cell line, 8505C, in vitro and 
inhibited tumorigenesis and metastasis in vivo. Therefore, the H19 may be an effective target for ATC molecular therapy [29].

UCA1 (Urothelial carcinomaassociated 1) serves as an oncogenic lncRNA [54] and is originally recognized in bladder transitional cell carcinoma [55]. Studies have shown that this lncRNA promotes tumor progression in a wide variety of cancers such as prostate cancer, gastric cancer, and esophageal cancer [56-58]. Wang et al. confirmed the oncogenic function of UCA1 in the progression of ATC. They showed that the expression levels of UCA1 increased in ATC tissue samples and cell lines. The results of this study indicated that UCA1 increases cell viability, proliferation, migration, and invasion in ATC in vitro and in vivo through binding to miR135a and regulation of cmyc expression. Several studies demonstrated that the expression of c-myc is upregulated in ATC, and targeting of cmyc may be a potential treatment for ATC [14].

Wang and colleagues examined a number of thyroid cancers which included 28 PTC and 10 ATC tissue samples using RT2 Profiler PCR Array Human Cancer Pathway Finder consisting of 84 lncRNAs to determine the specific lncRNAs that are overexpressed during thyroid cancer progression. They indicated that there are a significant number of lncRNAs that are expressed at higher levels in ATC compared with PTC such as HOTAIRM1 (Hox antisense intergenic RNA myeloid 1) and PCA3 (Prostate cancer antigen 3). The results of this study revealed that the IncRNAs HOTAIRM1 and PCA3 are upregulated during thyroid cancer development and progression [15]. The molecular mechanism of cancer caused by upregulation of HOTAIRM1 and PCA3 in ATC still remains unknown. However, because of their proven role in the progression of ATC, HOTAIRM1 and PCA3 may be used as effective targets for ATC molecular therapy. Since HOTAIRM1 and PCA3 are upregulated in various cancers [59-62]. These findings suggest that they may function as an oncogene in thyroid cancer, especially ATC. It should be noted that a number of evidences have shown that HOTAIRM1 can function either as a tumor suppressor or as a tumor promoter, depending on the type of cancer [61-63].

HCP5 (HLA complex P5) is dysregulated in a wide variety of cancers and diseases such as osteosarcoma [64], cervical cancer [65], and glioma [66] as well as psoriasis [67] and kawasaki disease [68]. Chen et al. showed that HCP5 is upregulated in ATC tissues. In this study, targeted inhibition of HCP5 with siRNA decreased cell viability and increased apoptosis in ATC cell lines. Mechanistically, HCP5 serves as a sponge for miR-128-3p and regulates the expression of miR-128-3p in ATC cell lines and tissues [16].
Du et al. found that Linc00210 (long intergenic nonprotein coding RNA 210) expression is increased in thyroid cancer tissues compared to the normal tissue samples. Overexpression of Linc00210 increased the proliferation, migration, and invasion of ATC cell line. Also, they found that Linc00210 directly bound to miR-195-5p and regulates the expression of IGF1R and the activation of PI3K/AKT signaling in ATC cell line. IGF/IGFR signaling pathway contributes to tumorigenesis and also drug resistance in thyroid cancer via activation of PI3K/AKT signaling pathway, leading to the expression of pro-survival genes and increased cell proliferation. Inhibition of IGF1R can decrease the responsiveness of thyroid cancer cells to growth factors [18].

Hou and colleagues revealed that TNRC6C-AS1 (TNRC6C antisense RNA 1) is upregulated in ATC tissues compared to adjacent normal tissues and ATC cell lines compared with normal human thyroid epithelial cells. In this study, targeted inhibition of TNRC6C-AS1 with shRNA decreased cell proliferation, migration, and invasion in ATC cell lines through downregulation of UNC5B expression and inhibited thyroid tumorigenesis in vivo. TNRC6C-AS1 serves as a competing endogenous RNA, (ceRNA) and upregulates the expression of UNC5B by sponging miR-129-5p in ATC cell lines. In addition, they found that the expression level of TNRC6C-AS1 in ATC cell lines is much higher than in follicular thyroid cancer (FTC) cell line [19]. Evidences showed that UNC5B, a target gene of miR-129-5p, act as a tumor suppressor in various cancers such as bladder cancer and pancreatic cancer. However, their findings came to opposite conclusion that UNC5B knockdown decreased thyroid cancer progression $[69,70]$.

Li et al. found that AK139328 expression is upregulated in thyroid cancer tissues including PTC and FTC as well as ATC cell line. Based on their findings, upregulating AK139328 expression increases cell viability, invasion, and cell cycle progression in ATC cell line opposing to the effect in groups with AK139328 knockdown using siRNA [20]. Identifying the molecular mechanism in which AK139328 serves as an oncogenic lncRNA in ATC as well as the therapeutic efficiency by targeted inhibition of AK139328 demands further examination. However, evidences showed that the silencing AK139328 can inhibit necrosis and caspase-3 activities following ischemia/reperfusion treatment [71].

Liu et al. demonstrated that thyroid cancer tissues have a higher expression of XIST (X-inactive specific transcript) than adjacent normal tissues. High expression of XIST was found in patients with larger tumor diameters, and advanced TNM stages (III and IV). They revealed that XIST acts as a ceRNA for miR-34a via sponging miR$34 \mathrm{a}$, competing with hepatocyte growth factor receptor 
(MET) for miR-34a binding, and decreasing ATC cell lines proliferation in vitro and tumor growth in vivo. Moreover, targeted inhibition of XIST could decrease the protein levels of MET, and the phosphorylation of PI3K and AKT [23]. Garcia and colleagues have recently indicated that MET overexpression and activation can increase cell invasion in ATC-derived cell line [72].

Chen et al.. revealed that SNHG7 (Small nucleolar RNA host gene 7) is overexpressed in thyroid cancer tissues by analyzing of The Cancer Genome Atlas (TCGA) datasets. The high expression levels of SNHG7 are correlated with advanced stages (III and IV) and shorter survival times in of thyroid cancer patients. Their funding showed that SNHG7 knockdown inhibits the cell proliferation and cell cycle progression of ATC cell line in vitro [24]. The molecular mechanism of ATC caused by upregulation of SNHG7 still remains unknown.

Evidences have shown that ZFAS1 (ZNFX1 antisense RNA 1) can function either as a tumor suppressor or as a tumor promoter, depending on the type of cancer cell. For example, ZFAS1 was first introduced as a tumor suppressor in breast cancer. But in hepatocellular carcinoma ZFAS1 serves as an oncogene and promotes cancer metastasis by regulating the expression of related genes such as MMP14 and MMP16 [73]. Han et al. revealed that ZFAS1 is highly expressed in thyroid cancer tissues, including ATC samples, compared to normal tissue samples by analyzing RNA-seq dataset of thyroid cancer from TCGA. ZFAS1 overexpression is positively associated with clinicopathological characteristics and poor prognosis in thyroid cancer. Targeted inhibition of ZFAS1 with siRNA decreased proliferation, and cell cycle progression in ATC cell line [26].

NEAT1 (Nuclear paraspeckle assembly transcript 1) acts as a ceRNA involved in several types of cancer. A number of evidences showed that NEAT1 has an important role in cancer chemoresistance. In addition, overexpression of NEAT1 is correlated with thyroid cancer progression by sponging miR214 and downregulation of NEAT1 is associated to suppression of PTC progression via the miR1295p/KLK7 axis [74]. Yan and colleagues indicated that NEAT1 is overexpressed in ATC cell lines and tissue samples, and NEAT1 silencing resulted in decreased cisplatinresistance of ATC through the regulating of miR95p/SPAG9 axis in vitro and in vivo [29]. Identifying the molecular mechanism in which NEAT1 serves as an oncogenic lncRNA in ATC as well as the therapeutic efficiency by targeted inhibition of NEAT1 demands further investigation.

\section{LncRNAs related to cancer stem cell properties in ATC}

Recent developments in cellular and molecular biology provide growing evidence that a specific subpopulation of tumor cells plays an important role in tumor initiation, invasion, and resistance to treatment in thyroid cancers, especially in ATC [30, 75-78]. These cells named tumorinitiating cells (TICs) or CSCs, have the stem cell-like properties such as the ability of self-renewal, colony formation, and EMT as well as induce resistance to chemotherapy and radiation therapy and telomerase reverse transcriptase (TERT) expression [30, 78-80]. EMT has a crucial role in tumor progression and invasion. During EMT, cells lose cellular adhesion and polarity and acquire an invasive phenotype $[78,81]$. Recent studies have indicated that lncRNAs play an essential role in the maintenance of CSCs and can modulate CSCs properties [82-84]. However, studies that have examined only the role of lncRNAs in thyroid CSCs, particularly in ATC, are scarce and in many cases, lncRNAs associated with CSCs properties overlap with their oncogenic or tumor suppressive function (Table 2).

ROR (Regulator of reprogramming) was first detected in induced pluripotent stem cells (iPSCs) [85, 86]. Hardin et al.. identified ROR in ATC cell line THJ-16T and CSC derived from the same ATC cell line by reverse transcription polymerase chain reaction (RT-PCR). According to their results, the expression level of ROR was higher in the CSC clone compared to the parental ATC cell line [30]. Recent research has suggested that ROR may exert its effect via modulation of the key pluripotency genes including OCT4, SOX2, and Nanog [30, 87, 88]. In another study, Hardin and colleagues focused on thyroid cancer stem-like cell exosomes which transfer lncRNAs involved in EMT. Exosomes are small (30-150 nm) membranous vesicles secreted by most cells that have an important role in cell-cell communication. They demonstrated that CSC exosomes transfer lncRNA ROR, to induce EMT in ATC cells. They also determined the lncRNA expression levels in CSC clones of ATC line compared to the parental line and found that MALAT1 and ROR are upregulated and HOTAIR (HOX transcript antisense RNA) and PVT1 (Plasmacytoma variant translocation 1) are downregulated. In addition, stem cell marker SOX2 and EMT marker SLUG had increased expression in CSC clonal lines compared to their parental ATC line. Evidences showed that MALAT1 is increased in PTC but significantly decreased in ATC and PVT1, HOTAIR, and ROR are downregulated in ATC compared to PTC [30]. The molecular mechanism that causes differences in the expression of these lncRNAs in ATC with PTC still remains unclear.

Some studies have shown that PVT1 is involved in poor prognosis of cancers [89, 90]. Zhou et al.. demonstrated that PVT1 expression is increased in ATC tissues and cell line compared with normal controls [31]. They indicated that the suppression of PVT1 causes cell cycle 
arrest at $G_{0} / G_{1}$ phase and significantly decreases cyclin D1 expression, thyroid stimulating hormone receptor (TSHR) expression, and the proliferation of thyroid cancer cells in ATC cell line [31]. In addition, Zhou and colleagues demonstrated that PVT1 could be enriched by enhancer of zeste homolog 2 (EZH2) [31], a marker of an advanced metastatic disease in numerous types of cancer including ATC [91-94], which may also contribute to the regulation of TSHR expression [31]. The authors finally proposed that PVT1 may contribute to pathogenesis of thyroid cancer through EZH2 recruitment and TSHR expression regulation [31].

MALAT1 (Metastasis-associated lung adenocarcinoma transcript 1) expression is associated with the tumor development, invasion, metastasis, and outcome in different types of cancer [95]. In addition, several reports have indicated that MALAT1 is expressed in CSCs of various cancers and has been linked to EMT [96, 97], a CSC feature [98-101]. Zhang et al.. analyzed 195 samples of normal/benign thyroid tissues as well as malignant thyroid neoplasms [100]. They indicated that expression of MALAT1 decreased during progression from normal thyroid tissue to ATC, but it is increased in PTC as compared to normal thyroid tissues. Based on their results, the greatest expression level occurs in PTC and the lowest expression level belongs to ATC in comparison to normal thyroid tissues [100]. Furthermore, they demonstrated that MALAT1 expression was elevated after inducing EMT in PTC cell line TPC-1 by tissue growth factor beta (TGF- $\beta$ ) [100]. Huang and colleagues also confirmed the upregulation of MALAT1 in differentiated thyroid cancers in comparison with adjacent normal thyroid tissues [102]. In addition, they showed that MALAT1 significantly increased in FTC and ATC cell lines compared to human normal breast epithelial cells, as the control with the highest expression level occurred in FTC and then in ATC cells [102]. However, in contrast to Zhang et al..s study [100], the MALAT1 expression level in ATC cell lines were not compared to normal thyroid cells in this study [102]. According to their results, MALAT1 exerts its effect by the upregulation of IQGAP1 [102], a key protein in regulating the cell adhesion and movement, which is also involved in EMT [102-105]. In addition, Huang and colleagues indicated that the overexpression of MALAT1 and IQGAP1 is correlated with the proliferation and invasion of thyroid cancer cells [102]. Another possible mechanism which MALAT1 may implicate its effect is the modulation of EZH2. EZH2 contributes to tumorigenesis and cancer progression, often through inactivation of tumor suppressor genes [31, 106]. According to our knowledge, the association between MALAT1 and EZH2 in ATC has not been evaluated yet. Nevertheless, several studies demonstrated that MALAT1 augments the oncogenic activities of EZH2 in different types of cancer [106-108]. As a result, EZH2 may be the common pathway through which PVT1 and MALAT1 apply their effects as an oncogene in ATC. In our previous study, we used 3D in vitro ATC model to determine the effect of BI-847,325 anticancer drug on MAPK signaling pathway via evaluating of the molecular mechanisms of MALAT1-mediated genes' regulation in ATC cell lines. The result of that study was the first report of MALAT1's molecular function in ATC and suggested that MALAT1 could be effective on cell cycle and apoptosis by regulating the expression of MALAT1-mediated cell cycle- and apoptosis-associated genes including Mcl1, miR-363-3p, and cyclin D1 [34]. In addition, Gou and colleagues showed that MALAT1 is upregulated in ATC cell lines. In this study, targeted inhibition of MALAT1 with siRNA decreased proliferation, migration, and invasion and increased apoptosis and autophagy formation in ATC cell line in vitro and inhibited tumorigenesis and metastasis in murine xenograft model through regulation of miR-200a-3p and FOXA1 expression. Therefore, the MALAT1 as a ceRNA may be an effective target for ATC molecular therapy [35]. Put together, these results suggest that MALAT1 plays an essential role in the pathogenesis of thyroid cancers and may have a significant role in anaplastic thyroid CSCs. However, further studies are needed to define its exact role in ATC.

Liu and colleagues used ATC cell line to determine the effect of flavonoid luteolin, a natural antioxidant, as anticancer drug on IncRNA BANCR (BRAF-activated nonprotein coding RNA) and its downstream genes. They showed that luteolin decreases cell growth and colony formation ability and increases cell cycle arrest at $\mathrm{G}_{1} / \mathrm{S}$ phases through modulation of BANCR/TSHR/CCND1 signaling pathway [36].

FOXD2-AS1 (FOXD2 adjacent opposite strand RNA 1 ) is an oncogenic lncRNA that is overexpressed in bladder cancer and promoted progression and recurrence via forming a positive feedback loop with AKT and E2F transcription factor 1 (E2F1) [109]. In addition, increased expression of this lncRNA in gastric cancer patients can predict poor prognosis and promotes tumorigenesis by epigenetically silencing EphB3 (EPH receptor B3) via EZH2 and LSD1, also known as KDM1A (lysine demethylase 1A) [110]. Liu et al. indicated that FOXD2-AS1 expression is upregulated in ATC tissues compared with the adjacent normal samples, through analyzing RNAseq dataset of thyroid cancer from TCGA database. FOXD2-AS1 overexpression is correlated with advanced TNM stags, recurrence status, and disease-free survival in thyroid cancer patients. Also, they found that the expression level of FOXD2-AS1 is increased in ATC cell 
lines compared with normal thyroid follicular epithelial cells. Their results showed that FOXD2-AS1 acts as a ceRNA for miR-7-5p, upregulating the expression of TERT, which increases the CSCs properties and anoikis resistance in thyroid cancer cells [111].

The expression of PTCSC3 (Papillary thyroid carcinoma susceptibility candidate 3 ) is strictly thyroid-specific and is downregulated in thyroid cancer. Wang et al.. indicated that PTCSC3 has a role in ATC by regulation STAT3/INO80 pathway. They reported that downregulation of PTCSC3 increases INO80 and MDR-1 expression through positively regulating STAT3, and thereby increasing drug resistance of ATC to Doxorubicin. Also, the results of this study indicated that INO80 influences on pluripotent state of CSCs by positively regulating ALDH and $\mathrm{CD}^{133}$ as stem cell markers in ATC tissues and cell line [38]. Fan and colleagues indicated the effect of PTCSC3 on cell growth, cell cycle, and apoptosis in ATC cell line. In this study, PTCSC3 is investigated as a competing endogenous RNA (ceRNA) for miR-574-5p [39]. Currently, there are no evidences about the role of miR574-5p in ATC. However, several studies demonstrated that miR-574-5p plays a role in proliferation, anchorage-independent growth of cancer cells, resistance to chemotherapy, and poor prognosis in patients with various cancers $[112,113]$.

$\mathrm{Lu}$ and colleagues revealed that higher MANCR (Mitotically associated long non coding RNA), also known as LINC00704, expression levels are associated with shorter overall survival time in thyroid cancer patients. In this study, targeted inhibition of MANCR with siRNA decreased EMT through upregulating E-cadherin and downregulating $\mathrm{N}$-cadherin and $\beta$-catenin expression, proliferation, and colony formation ability, as well as increased $G_{0} / G_{1}$ cell cycle arrest and apoptosis in ATC cell line in vitro [40].

Studies showed that PAR5 (Prader Wili/Angelman region RNA 5) is involeved in glioblastoma multiforme and its downregulation directly correlated with cancer progression [114]. Pllecchia et al.. assessed lncRNA expression profile of ATC tissues in comparison with normal thyroid samples through microarray. They identified 19 upregulated and 28 downregulated lncRNAs in ATC samples. Then, they evaluated the expression of three upregulated (MIAT, BCYRN1, BIC) and three downregulated (RMST, PAR5, IPW) lncRNAs to validate the microarray results. Subsequently, they found that PAR5 significantly and specifically downregulated in ATC. The restoration of PAR5 decreased colony formation ability, proliferation, and migration of ATC cell lines indicating that its downregulation contributes to ATC progression. They also showed that PAR5 interacts with EZH2 in ATC cell lines, reducing EZH2 protein levels and its binding on the E-cadherin promoter, relieving E-cadherin, as a key marker in switching EMT, from the negative regulation by EZH2 [41].

First, TUG1 (Taurine up-regulated gene 1) was identified as a potential lncRNA involved in mouse retinal development. Currently, the dysregulation of TUG1 has been reported in several cancers. Evidences revealed that TUG1 serves as ceRNA by sponging the miRNA or working via binding to polycomb repressive complex 2 (PRC2) [115]. Lei et al. indicated that TUG1 is an oncogenic lncRNA in thyroid cancer, and it is overexpressed in ATC cell lines compared with human normal breast epithelial cells. TUG1 can increase the proliferation, invasion, migration, and EMT of ATC cells. Their findings showed that miR-145 is a potential target of TUG1, and miR-145/ ZEB1 signaling pathway mediates the function of TUG1 in ATC cells [42].

\section{Conclusions}

In addition to genetic and epigenetic changes, other biological mechanisms including lncRNAs play a crucial role in regulation of approximately all steps of cancer progression. LncRNAs can affect on molecular mechanisms involved in the development and progression of ATC including the regulation of epigenetic factors and expression of genes and miRNAs associated with proliferation, invasion, metastasis, cell cycle, apoptosis as well as stem cell-like properties of CSCs such as EMT and colony formation (Table 3). For most lncRNAs, only a single experiment has evaluated the expression profile in ATC tissues and/or cells. Therefore, there is no way for comparison and verification studies. Consequently, further functional studies and expression profiling in larger sample sizes are needed to resolve this limitation and identify novel and valid biomarkers.

Analysis of lncRNAs in ATC can be an interesting field, which will lead to identification of novel diagnosis and prognosis markers, because of the advantages such as noninvasiveness and easy access. At present, only a few parts of lncRNAs have been identified in ATC that may serve as prognosis markers such as GAS5, MIR22HG, and CASC2. Also, because of the dysregulation of Klhl14AS, HOTAIRM1, and PCA3 during ATC development and progression, they may act as therapeutic targets. The measurement of lncRNAs in blood and fine needle aspiration biopsy of ATC patients can be useful as an adjunct to improving diagnosis and prognostication. However, further studies are required to determine the exact function of lncRNAs in the development and progression of ATC, which can contribute to the identification of novel and valid biomarkers, as well as possible therapeutic targets in ATC. 


\section{Abbreviations}

AKT: AKT serine/threonine kinase; ALDH1: aldehyde dehydrogenase 1; ATC : anaplastic thyroid cancer; BANCR: BRAF-activated non-protein coding RNA; BCL2: BCL2 apoptosis regulator; BCYRN1: brain cytoplasmic RNA 1; BRAF: B-raf proto-oncogene; CASC2: cancer susceptibility candidate 2; CCND1: cyclin D1; CDK6: cycling-dependent kinase 6; ceRNA: competing endogenous RNA; c-myc: avian myeocytomatosis virus oncogene cellular homolog; CSC: cancer stem cell; EMT: epithelial to mesenchymal transition; EZH2: enhancer of zeste homolog 2; FOXA1: forkhead box protein A1; FOXD2-AS1: FOXD2 Adjacent Opposite Strand RNA 1; FTC: follicular thyroid cancer; GAS5: growth arrest special 5; HCP5: HLA complex P5; HOTAIR: HOX transcript antisense RNA; HOTAIRM 1: HOX antisense intergenic RNA myeloid 1; IGF: insulin growth factor; IGF1R: insulin like growth factor 1 receptor; INO80: INO80 complex ATPase subunit; iPSC: induced pluripotent stem cell; IPW: imprinted in prader-willi syndrome; IQGAP1: Ras GTPase-activating-like protein; KIhl14: kelch like family member 14; KLK7: kallikrein related peptidase 7; Linc00210: long intergenic non-protein coding RNA 210; LINC00312: long intergenic non-protein coding RNA 312; LncRNA: long noncoding RNA; MALAT1: metastasis-associated lung adenocarcinoma transcript 1; MANCR: mitotically associated long non coding RNA; MAPK: mitogen-activated protein kinase; Mcl1: myeloid cell leukemia 1; MDR-1: multidrug resistance protein 1; MET: MET protooncogene; MIAT: myocardial infarction associated transcript; miR: microRNA; MIR22HG: MIR22 host gene; miRNA: microRNA; MMP16: matrix metallopeptidase 16; CRNA: noncoding RNA; NEAT1: nuclear paraspeckle assembly transcript 1; OCT4: octamerbinding transcription factor 4; PAR5: Prader Wili/Angelman region RNA 5; PAX8: paired box 1; PCA3: prostate cancer antigen 3; PI3K: phosphatidylinositol-3-kinas; piRNA: piwi-interacting RNA; PRC2: polycomb repressive complex 2; PTC: papillary thyroid cancer; PTCSC3: papillary thyroid carcinoma susceptibility candidate 3; PVT1: plasmacytoma variant translocation 1; RAS: RAS protooncogene; RMST: rhabdomyosarcoma 2 associated transcript; RNA-seq: RNA sequencing; ROR: regulator of reprogramming; RT-PCR: reverse transcription polymerase chain reaction; ShRNA: short hairpin RNA; siRNA: small interfering RNA; SNHG 15: small nucleolar RNA host gene 15; SNHG7: small nucleolar RNA host gene 7; SOX2: SRY-box transcription factor 2; SPAG9: sperm associated antigene 9; STAT3: signal transducer and activator of transcription 3; TCGA: the cancer genome atlas; TERT: telomerase reverse transcriptase; TGF- $\beta$ : tissue growth factor beta; TIC: tumor-initiating cell; TNM: tumor-node-metastasis; TNRC6C-AS1: TNRC6C antisense RNA 1;TSHR: thyroid stimulating hormone receptor; TUG1: taurine up-regulated gene 1; UCA1: urothelial carcinoma-associated 1; UNC5B: unc-5 netrin receptor B; XIST: X inactive specific transcript; ZEB1: zinc finger E-box binding homeobox 1; ZFAS1: ZNFX1 antisense RNA 1.

\section{Acknowledgements}

Not applicable.

\section{Authors' contributions}

$\mathrm{HS}$ and VH create the idea. HS, HM, MAF and VH discussed the concept and designed the study. RA performed the literature search. HS, SMSJ, and SS collected and analyzed the data. HS wrote the first draft of the manuscript. All authors read and approved the final manuscript.

\section{Funding}

This research did not receive any specific grant from funding agencies in the public, commercial, or not-for-profit sectors.

\section{Availability of data and materials}

Not applicable.

\section{Ethics approval and consent to participate}

Not applicable.

\section{Consent for publication}

Not applicable.

\section{Competing interests}

The authors declare that they have no conflict of interest.

\section{Author details}

${ }^{1}$ Endocrinology and Metabolism Research Center, Endocrinology and Metabolism Clinical Sciences Institute, Tehran University of Medical Sciences, Tehran, Iran. ${ }^{2}$ Cell Therapy and Regenerative Medicine Research Center,
Endocrinology and Metabolism Molecular-Cellular Sciences Institute, Tehran University of Medical Sciences, Tehran, Iran. ${ }^{3}$ Division of Cardiology, Department of Medicine, Beth Israel Deaconess Medical Center, Harvard Medical School, PERFUSE Study Group, Boston, MA, USA. ${ }^{4}$ Evidence Based Practice Research Center, Endocrinology and Metabolism Clinical Sciences Institute, Tehran University of Medical Sciences, Tehran, Iran. ${ }^{5}$ Department of Surgery, Iranian National Cancer Institute, Imam Khomeini Complex, Tehran University of Medical Sciences, Tehran, Iran. ${ }^{6}$ Persian BayanGene Research and Training Center, Dr. Faghihi's Medical Genetic Center, Shiraz, Iran. ${ }^{7}$ Department of Psychiatry and Behavioral Sciences, University of Miami Miller School of Medicine, Miami, USA. ${ }^{8}$ Personalized Medicine Research Center, Endocrinology and Metabolism Clinical Sciences Institute, Tehran University of Medical Sciences, Tehran, Iran. ${ }^{9}$ Endocrinology and Metabolism Research Center (EMRC), Dr. Shariati Hospital, North Kargar Ave., Tehran 14114, Iran.

Received: 5 May 2020 Revised: 11 June 2020 Accepted: 20 July 2020 Published online: 29 July 2020

\section{References}

1. Nikiforov YE, Nikiforova MN. Molecular genetics and diagnosis of thyroid cancer. Nat Rev Endocrinol. 2011;7(10):569.

2. LiVolsi VA. Papillary thyroid carcinoma: an update. Mod Pathol. 2011;24(S2):1

3. Fagin JA, Wells SA Jr. Biologic and clinical perspectives on thyroid cancer. N Engl J Med. 2016;375(11):1054-67.

4. Xing M. Molecular pathogenesis and mechanisms of thyroid cancer. Nat Rev Cancer. 2013;13(3):184.

5. Samimi H, Fallah P, Sohi AN, Tavakoli R, Naderi M, Soleimani M, Larijani B, Haghpanah V. Precision medicine approach to anaplastic thyroid cancer: advances in targeted drug therapy based on specific signaling pathways. Acta Med Iran. 2017;55(3):200-8.

6. Samimi H, Ghadami M, Khashayar P, Soleimani M, Larijani B, Haghpanah V. MicroRNAs networks in thyroid cancers: focus on miRNAs related to the fascin. J Diabetes Metab Disord. 2013;12(1):31.

7. Smith N, Nucera C. Personalized therapy in patients with anaplastic thyroid cancer: targeting genetic and epigenetic alterations. J Clin Endocrinol Metab. 2015;100(1):35-42.

8. Zhang R, Hardin H, Chen J, Guo Z, Lloyd RV. Non-coding RNAs in thyroid cancer. Endocr Pathol. 2016;27(1):12-20.

9. Sui F, Ji M, Hou P. Long non-coding RNAs in thyroid cancer: biological functions and clinical significance. Mol Cell Endocrinol. 2017;469:11.

10. Murugan AK, Munirajan AK, Alzahrani AS. Long noncoding RNAs: emerging players in thyroid cancer pathogenesis. Endocr Relat Cancer. 2018;25(2):R59-82.

11. Kim D, Lee WK, Jeong S, Seol M-Y, Kim H, Kim K-S, Lee EJ, Lee J, Jo YS. Upregulation of long noncoding RNA LOC100507661 promotes tumor aggressiveness in thyroid cancer. Mol Cell Endocrinol. 2016;431:36-45.

12. Guo L-J, Zhang S, Gao B, Jiang Y, Zhang X-H, Tian W-G, Hao S, Zhao J-J, Zhang G, Hu C-Y. Low expression of long non-coding RNA GAS5 is associated with poor prognosis of patients with thyroid cancer. Exp Mol Pathol. 2017;102(3):500-4.

13. Zhang H. Targeted inhibition of long non-coding RNA H19 blocks anaplastic thyroid carcinoma growth and metastasis. J Cell Mol Med. 2019;10(1):306-15.

14. Wang Y, Hou Z, Li D. Long noncoding RNA UCA1 promotes anaplastic thyroid cancer cell proliferation via miR-135a-mediated c-myc activation. Mol Med Rep. 2018;18(3):3068-76.

15. Wang Y, Hardin H, Chu Y-H, Esbona K, Zhang R, Lloyd RV. Long noncoding RNA expression in anaplastic thyroid carcinomas. Endocr Pathol. 2019;1:8.

16. Chen J, Zhao D, Meng Q. Knockdown of HCP5 exerts tumor-suppressive functions by up-regulating tumor suppressor miR-128-3p in anaplastic thyroid cancer. Biomed Pharmacother. 2019;116:108966.

17. Credendino SC, Bellone ML, Lewin N, Amendola E, Sanges R, Basu S, Sepe R. A ceRNA Circuitry Involving the Long Noncoding RNA KIhl14-AS, Pax8, and Bcl2 Drives Thyroid Carcinogenesis. Cancer Res. 2019;79(22):5746-57. 
18. Du P, Liu F, Liu Y, Shao M, Li X, Qin G. Linc00210 enhances the malignancy of thyroid cancer cells by modulating miR-195-5p/IGF1R/Akt axis. J Cell Physiol. 2020;235(2):1001-12.

19. Hou S, Lin Q, Guan F, Lin C. LnCRNA TNRC6C-AS1 regulates UNC5B in thyroid cancer to influence cell proliferation, migration, and invasion as a competing endogenous RNA of miR-129-5p. J Cell Biochem. 2018;119(10):8304-16.

20. Li SQ, Zhao ZJ, Li Y, Zhang Y, Dong LY, Liang Y, Mao Y, Ma JF. The long noncoding RNA AK139328 promotes the oncogenesis in thyroid cancer. Int J Clin Exp Med. 2017;10(8):11894-902.

21. Song WH, Lu BY, Huang YB, Dong HM, Ma XK, Zhu ZZ, Zhou R, Liu K, Huang W, Yan DQ, et al. Overexpression of long intergenic noncoding RNA LINC00312 inhibits the invasion and migration of thyroid cancer cells by down-regulating microRNA-197-3p. J Cell Biochem. 2017;37:4.

22. Min X, Liu K, Zhu H, Zhang J. Long noncoding RNA LINC003121 inhibits proliferation and invasion of thyroid cancer cells by suppression of the phosphatidylinositol-3-Kinase (PI3K)/Akt Signaling Pathway. Med Sci Monit. 2018;24:4592-601.

23. Liu H, Deng HY, Zhao YJ, Li C, Liang Y. LncRNA XIST/miR-34a axis modulates the cell proliferation and tumor growth of thyroid cancer through MET-PI3K-AKT signaling. J Exp Clin Cancer Res. 2018;37:23.

24. Chen L, Zhu J, Zhang LJ. Long non-coding RNA small nucleolar RNA host gene 7 is upregulated and promotes cell proliferation in thyroid cancer. Oncol Lett. 2019;18(5):4726-34.

25. Liu YC, Li JL, Li M, Li F, Shao Y, Wu LP. microRNA-510-5p promotes thyroid cancer cell proliferation, migration, and invasion through suppressing SNHG15. J Cell Biochem. 2019;120(7):11738-44.

26. Han CG, Huang Y, Qin L. Long non-coding RNA ZFAS1 as a novel potential biomarker for predicting the prognosis of thyroid cancer. Med Sci Monit. 2019:25:2984-92.

27. Qin L, Luo JZ, Tang XL, Han CG. Identification of long noncoding RNA MIR22HG as a novel biomarker in thyroid cancer. J Cell Biochem. 2019;25(2):703-10.

28. Xiong $\mathrm{X}$, Zhu H, Chen $\mathrm{X}$. Low expression of long noncoding RNA CASC2 indicates a poor prognosis and promotes tumorigenesis in thyroid carcinoma. Biomed Pharmacother. 2017;93:391-7.

29. Zhang H, Yu Y, Zhang K, Liu X, Dai Y, Jiao X. Targeted inhibition of long non-coding RNA H19 blocks anaplastic thyroid carcinoma growth and metastasis. Bioengineered. 2019:10(1):306-15.

30. Hardin H, Helein H, Meyer K, Robertson S, Zhang R, Zhong W, Lloyd RV. Thyroid cancer stem-like cell exosomes: regulation of EMT via transfer of IncRNAs. J Cell Biochem. 2018;98(9):1133-42.

31. Zhou Q, Chen J, Feng J, Wang J. Long noncoding RNA PVT1 modulates thyroid cancer cell proliferation by recruiting EZH2 and regulating thyroid-stimulating hormone receptor (TSHR). Tumor Biol. 2016;37(3):3105-13.

32. Huang JK, Ma L, Song WH, Lu BY, Huang YB, Dong HM, Ma XK, Zhu ZZ, Zhou R. MALAT1 promotes the proliferation and invasion of thyroid cancer cells via regulating the expression of IQGAP1. Biomed Pharmacother. 2016:83:1-7.

33. Zhang R, Hardin H, Huang W, Chen J, Asioli S, Righi A, Maletta F, Sapino A, Lloyd RV. MALAT1 long non-coding RNA expression in thyroid tissues: analysis by in situ hybridization and real-time PCR. Endocr Pathol. 2017:28(1):7-12.

34. Samimi H, Haghpanah V, Irani S, Arefian E, Sohi AN, Fallah P, Soleimani M. Transcript-level regulation of MALAT1-mediated cell cycle and apoptosis genes using dual MEK/Aurora kinase inhibitor "BI-847325" on anaplastic thyroid carcinoma. DARU J Pharm Sci. 2019;27(1):1-7.

35. Gou L, Zou H, Li B. Long noncoding RNA MALAT1 knockdown inhibits progression of anaplastic thyroid carcinoma by regulating miR200a-3p/FOXA1. Cancer Biol Ther. 2019;20(11):1355-65.

36. Liu C, Lin Y, Xu J, Chu H, Hao S, Liu X, Song X, Jiang L, Zheng H. Luteolin suppresses tumor progression through IncRNA BANCR and its downstream TSHR/CCND1 signaling in thyroid carcinoma. Sci Rep. 2017:10(9):9591-8.

37. Liu XL, Fu QF, Li SJ, Liang N, Li F, Li CL, Sui CQ, Dionigi G, Sun H. LnCRNA FOXD2-AS1 functions as a competing endogenous RNA to regulate TERT expression by sponging miR-7-5p in thyroid cancer. Front Endocrinol. 2019;10:207.
38. Wang X-m, Liu Y, Fan Y-X, Liu Z, Yuan Q-I, Jia M, Geng Z-s, Gu L. Lu X-b: LncRNA PTCSC3 affects drug resistance of anaplastic thyroid cancer through STAT3/INO80 pathway. Cancer Biol Ther. 2018;19(7):590-7.

39. Fan M, Li X, Jiang W, Huang Y, Li J, Wang Z. A long non-coding RNA, PTCSC3, as a tumor suppressor and a target of miRNAs in thyroid cancer cells. Exp Ther Med. 2013;5(4):1143-6.

40. Lu W, Xu Y, Xu J, Wang Z, Ye G. Identification of differential expressed IncRNAs in human thyroid cancer by a genome-wide analyses. Cancer Med. 2018;7(8):3935-44.

41. Pellecchia S. The long non-coding RNA Prader Willi/Angelman Region RNA5 (PAR5) is downregulated in anaplastic thyroid carcinomas where it acts as a tumor suppressor by reducing EZH2 Activity. Cancers. 2020;12:1

42. Lei H, Gao Y, Xu X. LncRNA TUG1 influences papillary thyroid cancer cell proliferation, migration and EMT formation through targeting miR-145. Acta Biochim Biophys Sin. 2017:49(7):588-97.

43. Gupta RA, Shah N, Wang KC, Kim J, Horlings HM, Wong DJ, Tsai M-C, Hung T, Argani P, Rinn JL. Long non-coding RNA HOTAIR reprograms chromatin state to promote cancer metastasis. Nature. 2010;464(7291):1071.

44. He X, Liu Z, Su J, Yang J, Yin D, Han L, De W, Guo R. Low expression of long noncoding RNA CASC2 indicates a poor prognosis and regulates cell proliferation in non-small cell lung cancer. Tumor Biol. 2016;37(7):9503-10

45. Liu Z, Wang W, Jiang J, Bao E, Xu D, Zeng Y, Tao L, Qiu J. Downregulation of GAS5 promotes bladder cancer cell proliferation, partly by regulating CDK6. PLOS ONE. 2013;8(9):e73991.

46. Hamada S, Satoh K, Miura S, Hirota M, Kanno A, Masamune A, Kikuta K, Kume K, Unno J, Egawa S. miR-197 induces epithelial-mesenchymal transition in pancreatic cancer cells by targeting p120 catenin. J Cell Physiol. 2013;228(6):1255-63.

47. Stairs DB, Bayne LJ, Rhoades B, Vega ME, Waldron TJ, Kalabis J, KleinSzanto A, Lee J-S, Katz JP, Diehl JA. Deletion of p120-catenin results in a tumor microenvironment with inflammation and cancer that establishes it as a tumor suppressor gene. Cancer Cell. 2011;19(4):470-83.

48. Zou D, Wang D, Li R, Tang Y, Yuan L, Long X, Zhou Q. MiR-197 induces Taxol resistance in human ovarian cancer cells by regulating NLK. Tumor Biol. 2015:36(9):6725-32.

49. Björklund $M$, Koivunen E. Gelatinase-mediated migration and invasion of cancer cells. Biochim Biophys Acta. 2005;1755(1):37-69.

50. Bauvois B. New facets of matrix metalloproteinases MMP-2 and MMP-9 as cell surface transducers: outside-in signaling and relationship to tumor progression. Biochimica Biochim Biophys Acta. 2012;1825(1):29-36.

51. Baldini E, Toller M, Graziano F, Russo F, Pepe M, Biordi L, Marchioni E, Curcio F, Ulisse S, Ambesi-Impiombato F. Expression of matrix metalloproteinases and their specific inhibitors in normal and different human thyroid tumor cell lines. Thyroid. 2004;14(11):881-8.

52. Su W, Feng $S$, Chen X, Yang X, Mao R, Guo C, Wang Z, Thomas DG, Lin $J$, Reddy RM. Silencing of long noncoding RNA MIR22HG triggers cell survival/death signaling via oncogenes YBX1, MET, and p21 in lung cancer. Cancer Res. 2018;78(12):3207-19.

53. Liu Y, Li J, Li F, Li M, Shao Y, Wu L. SNHG15 functions as a tumor suppressor in thyroid cancer. J Cell Biochem. 2019;120(4):6120-6.

54. Li F, Hu C-P. Long non-coding RNA urothelial carcinoma associated 1 (UCA1): insight into its role in human diseases. Crit Rev Eukaryot Gene Expr. 2015;25:3.

55. Wang F, Li X, Xie X, Zhao L, Chen W. UCA1, a non-protein-coding RNA up-regulated in bladder carcinoma and embryo, influencing cell growth and promoting invasion. FEBS Lett. 2008;582(13):1919-27.

56. Zhang S, Dong X, Ji T, Chen G, Shan L. Long non-coding RNA UCA1 promotes cell progression by acting as a competing endogenous RNA of ATF2 in prostate cancer. Am J TransI Res. 2017;9(2):366.

57. Jiao C, Song Z, Chen J, Zhong J, Cai W, Tian S, Chen S, Yi Y, Xiao Y. InCRNA-UCA1 enhances cell proliferation through functioning as a ceRNA of Sox4 in esophageal cancer. Oncol Rep. 2016;36(5):2960-6.

58. Wang Z-Q, Cai Q, Hu L, He C-Y, Li J-F, Quan Z-W, Liu B-Y, Li C, Zhu Z-G. Long noncoding RNA UCA1 induced by SP1 promotes cell proliferation via recruiting EZH2 and activating AKT pathway in gastric cancer. Cell Death Dis. 2017:8(6):e2839-9. 
59. Liu Y, Zong Z-H, Guan X, Wang L-I, Zhao Y. The role of long non-coding RNA PCA3 in epithelial ovarian carcinoma tumorigenesis and progression. Gene. 2017:633:42-7.

60. Sajjadi E, Atashi A, Tajrishi MAMH, Saei Z. Gene expression analysis of noncoding PCA3 gene in patients with chronic myeloid leukemia. J Cancer Res Ther. 2018;14(5):1079.

61. Luo Y, He Y, Ye X, Song J, Wang Q, Li Y, Xie X. High expression of long noncoding RNA HOTAIRM1 is associated with the proliferation and migration in pancreatic ductal adenocarcinoma. Pathol Oncol Res. 2019;25(4):1567-77.

62. Li Q, Dong C, Cui J, Wang Y, Hong X. Over-expressed IncRNA HOTAIRM1 promotes tumor growth and invasion through up-regulating HOXA1 and sequestering G9a/EZH2/Dnmts away from the HOXA1 gene in glioblastoma multiforme. J Exp Clin Cancer Res. 2018;37(1):1-15.

63. Wan L, Kong J, Tang J, Wu Y, Xu E, Lai M, Zhang H. HOTAIRM 1 as a potential biomarker for diagnosis of colorectal cancer functions the role in the tumour suppressor. J Cell Mol Med. 2016;20(11):2036-44.

64. Zhao W, Li L. SP1-induced upregulation of long non-coding RNA HCP5 promotes the development of osteosarcoma. Pathol Res Pract. 2019:215(3):439-45

65. Yu Y, Shen H, Fang D, Meng $Q$, Xin Y. LncRNA HCP5 promotes the development of cervical cancer by regulating MACC1 via suppression of microRNA-15a. Eur Rev Med Pharmacol Sci. 2018;22(15):4812-9.

66. Teng H, Wang P, Xue Y, Liu X, Ma J, Cai H, Xi Z, Li Z, Liu Y. Role of HCP5miR-139-RUNX1 feedback loop in regulating malignant behavior of glioma cells. Mol Ther. 2016;24(10):1806-22.

67. Li XL, Yu H, Wu GS. Investigating the genetic association of HCP 5, SPATA 2, TNIP 1, TNFAIP 3 and COG 6 with psoriasis in C hinese population. Int J Immunogenet. 2014;41(6):503-7.

68. Kim J-J, Yun SW, Yu JJ, Yoon KL, Lee K-Y, Kil H-R, Kim GB, Han M-K, Song MS, Lee HD. A genome-wide association analysis identifies NMNAT2 and HCP5 as susceptibility loci for Kawasaki disease. J Hum Genet. 2017:62(12):1023-9.

69. Liu J, Kong C-Z, Gong D-X, Zhang Z, Zhu Y. -y: PKC a regulates netrin-1/ UNC5B-mediated survival pathway in bladder cancer. BMC Cancer. 2014;14(1):93.

70. An X-Z, Zhao Z-G, Luo Y-X, Zhang R, Tang X-Q, Hao D-L, Zhao X, Lv X, Liu D-P. Netrin-1 suppresses the MEK/ERK pathway and ITGB4 in pancreatic cancer. Oncotarget. 2016;7(17):24719.

71. Chen Z, Jia S, Li D, Cai J, Tu J, Geng B, Guan Y, Cui Q, Yang J. Silencing of long noncoding RNA AK139328 attenuates ischemia/reperfusion injury in mouse livers. PLoS ONE. 2013;8:11

72. Garcia C, Buffet C, El Khattabi L, Rizk-Rabin M, Perlemoine K, Ragazzon B, Bertherat J, Cormier F, Groussin L. MET overexpression and activation favors invasiveness in a model of anaplastic thyroid cancer. Oncotarget. 2019:10(23):2320

73. Li T, Xie J, Shen C, Cheng D, Shi Y, Wu Z, Deng X, Chen H, Shen B, Peng C. Amplification of long noncoding RNA ZFAS1 promotes metastasis in hepatocellular carcinoma. Cancer Res. 2015;75(15):3181-91.

74. Zhang H, Cai Y, Zheng L, Zhang Z, Lin X, Jiang N. Long noncoding RNA NEAT1 regulate papillary thyroid cancer progression by modulating miR-129-5p/KLK7 expression. J Cell Physiol. 2018;233(10):6638-48.

75. Zhang P, Zuo H, Ozaki T, Nakagomi N, Kakudo K. Cancer stem cell hypothesis in thyroid cancer. Pathol Int. 2006;56(9):485-9.

76. Carina V, Zito G, Pizzolanti G, Richiusa P, Criscimanna A, Rodolico V, Tomasello L, Pitrone M, Arancio W, Giordano C. Multiple pluripotent stem cell markers in human anaplastic thyroid cancer: the putative upstream role of SOX2. Thyroid. 2013;23(7):829-37.

77. Haghpanah V, Fallah P, Naderi M, Tavakoli R, Soleimani M, Larijani B. Cancer stem-like cell behavior in anaplastic thyroid cancer: A challenging dilemma. Life Sci. 2016;146:34-9.

78. Guo Z, Hardin H, Lloyd RV. Cancer stem-like cells and thyroid cancer. Endocr Relat Cancer. 2014;21(5):T285-300.

79. Mitsutake N, Iwao A, Nagai K, Namba H, Ohtsuru A, Saenko V, Yamashita S. Characterization of side population in thyroid cancer cell lines: cancer stem-like cells are enriched partly but not exclusively. Endocrinology. 2007;148(4):1797-803

80. Jung CW, Han KH, Seol H, Park S, Koh JS, Lee S-S, Kim MJ, Choi IJ, Myung $J K$. Expression of cancer stem cell markers and epithelial-mesenchymal transition-related factors in anaplastic thyroid carcinoma. Int J Clin Exp Pathol. 2015;8(1):560.
81. Floor S, Van Staveren W, Larsimont D, Dumont J, Maenhaut C. Cancer cells in epithelial-to-mesenchymal transition and tumor-propagatingcancer stem cells: distinct, overlapping or same populations. Oncogene. 2011;30(46):4609.

82. Huang T, Alvarez A, Hu B, Cheng S-Y. Noncoding RNAs in cancer and cancer stem cells. Chin J Cancer. 2013;32(11):582.

83. Fatica A, Bozzoni I. Long non-coding RNAs: new players in cell differentiation and development. Nat Rev Genet. 2014;15(1):7.

84. Schmitt AM, Chang HY. Long noncoding RNAs in cancer pathways. Cancer Cell. 2016;29(4):452-63.

85. Pan Y, Li C, Chen J, Zhang K, Chu X, Wang R, Chen L. The emerging roles of long noncoding RNA ROR (lincRNA-ROR) and its possible mechanisms in human cancers. Cell Physiol Biochem. 2016;40(1-2):219-29.

86. Aiello A, Pandini G, Frasca F, Conte E, Murabito A, Sacco A, Genua M, Vigneri R, Belfiore A. Peroxisomal proliferator-activated receptor- $\gamma$ agonists induce partial reversion of epithelial-mesenchymal transition in anaplastic thyroid cancer cells. Endocrinology. 2006;147(9):4463-75.

87. Wang Y, Xu Z, Jiang J, Xu C, Kang J, Xiao L, Wu M, Xiong J, Guo X, Liu $H$. Endogenous miRNA sponge lincRNA-RoR regulates Oct4, Nanog, and Sox2 in human embryonic stem cell self-renewal. Dev Cell. 2013;25(1):69-80.

88. Gao S, Wang P, Hua Y, Xi H, Meng Z, Liu T, Chen Z, Liu L. ROR functions as a ceRNA to regulate Nanog expression by sponging miR-145 and predicts poor prognosis in pancreatic cancer. Oncotarget. 2016;7(2):1608

89. Huang C, Liu S, Wang H, Zhang Z, Yang Q, Gao F. LncRNA PVT1 overexpression is a poor prognostic biomarker and regulates migration and invasion in small cell lung cancer. Am J Transl Res. 2016;8(11):5025.

90. Iden M, Fye S, Li K, Chowdhury T, Ramchandran R, Rader JS. The IncRNA PVT1 contributes to the cervical cancer phenotype and associates with poor patient prognosis. PLoS One. 2016;11 (5):e0156274.

91. Masudo K, Suganuma N, Nakayama H, Oshima T, Rino Y, Iwasaki H, Matsuzu K, Sugino K, Ito K, Kondo T. EZH2 overexpression as a useful prognostic marker for aggressive behaviour in thyroid cancer. In vivo. 2018;32(1):25-31.

92. Borbone E, Troncone G, Ferraro A, Jasencakova Z, Stojic L, Esposito F, Hornig N, Fusco A, Orlando V. Enhancer of zeste homolog 2 overexpression has a role in the development of anaplastic thyroid carcinomas. J Clin Endocrinol Metab. 2011;96(4):1029-38.

93. Chase A, Cross NC. Aberrations of EZH2 in cancer. Clin Cancer Res. 2011;17:2613-8.

94. Kleer CG, Cao Q, Varambally S, Shen R, Ota I, Tomlins SA, Ghosh D, Sewalt RG, Otte AP, Hayes DF. EZH2 is a marker of aggressive breast cancer and promotes neoplastic transformation of breast epithelial cells. Proc Natl Acad Sci USA. 2003;100(20):11606-11.

95. Ma X-Y, Wang J-H, Wang J-L, Ma CX, Wang X-C, Liu F-S. Malat1 as an evolutionarily conserved InCRNA, plays a positive role in regulating proliferation and maintaining undifferentiated status of early-stage hematopoietic cells. BMC Genom. 2015;16(1)::676.

96. Heery R, Finn S, Cuffe S, Gray S. Long non-coding RNAs: key regulators of epithelial-mesenchymal transition, tumour drug resistance and cancer stem cells. Cancers. 2017;9(4):38.

97. Jiao F, Hu H, Han T, Yuan C, Wang L, Jin Z, Guo Z, Wang L. Long noncoding RNA MALAT-1 enhances stem cell-like phenotypes in pancreatic cancer cells. Int J Mol Sci. 2015;16(4):6677-93.

98. Hardin H, Guo Z, Shan W, Montemayor-Garcia C, Asioli S, Yu X-M, Harrison AD, Chen H, Lloyd RV. The roles of the epithelial-mesenchymal transition marker PRRX1 and miR-146b-5p in papillary thyroid carcinoma progression. Am J Pathol. 2014;184(8):2342-54.

99. Mani SA, Guo W, Liao M-J, Eaton EN, Ayyanan A, Zhou AY, Brooks M, Reinhard F, Zhang CC, Shipitsin M. The epithelial-mesenchymal transition generates cells with properties of stem cells. Cell. 2008;133(4):704-15.

100. Zhang R, Hardin H, Huang W, Chen J, Asioli S, Righi A, Maletta F, Sapino A, Lloyd RV. MALAT1 long non-coding RNA expression in thyroid tissues: analysis by in situ hybridization and real-time PCR. Endocr Pathol. 2017;28(1):7-12.

101. Dongre A, Weinberg RA. New insights into the mechanisms of epithelial-mesenchymal transition and implications for cancer. Nat Rev Mol Cell Biol. 2018;20:69.

102. Huang J-K, Ma L, Song W-H, Lu B-Y, Huang Y-B, Dong H-M, Ma X-K. MALAT1 promotes the proliferation and invasion of thyroid cancer 
cells via regulating the expression of IQGAP1. Biomed Pharmacother. 2016:83:1-7.

103. Zeng F, Jiang W, Zhao W, Fan Y, Zhu Y, Zhang H. Ras GTPase-ActivatingLike Protein IQGAP1 (IQGAP1) promotes breast cancer proliferation and invasion and correlates with poor clinical outcomes. Med Sci Monit. 2018;24:3315.

104. Smith A, Teknos TN, Pan Q. Epithelial to mesenchymal transition in head and neck squamous cell carcinoma. Oral Oncol. 2013;49(4):287-92.

105. Gumbiner BM. Regulation of cadherin adhesive activity. J Ccell Biol. 2000;148(3):399-404.

106. Qi Y, Ooi HS, Wu J, Chen J, Zhang X, Tan S, Yu Q, Li Y-Y, Kang Y, Li H. MALAT1 long ncRNA promotes gastric cancer metastasis by suppressing PCDH10. Oncotarget. 2016;7(11):12693.

107. Wang D, Ding L, Wang L, Zhao Y, Sun Z, Karnes RJ, Zhang J, Huang H. LnCRNA MALAT1 enhances oncogenic activities of EZH2 in castrationresistant prostate cancer. Oncotarget. 2015;6(38)::41045.

108. Kim SH, Kim SH, Yang WI, Kim SJ, Yoon SO. Association of the long noncoding RNA MALAT1 with the polycomb repressive complex pathway in T and NK cell lymphoma. Oncotarget. 2017;8(19):31305.

109. Su F, He W, Chen C, Liu M, Liu H, Xue F, Bi J, Xu D, Zhao Y, Huang J. The long non-coding RNA FOXD2-AS1 promotes bladder cancer progression and recurrence through a positive feedback loop with Akt and E2F1. Cell Death Dis. 2018;9(2):1-17.

110. Xu T-p, Wang W-y, Ma P, Shuai Y, Zhao K, Wang Y-f, Li W, Xia R, Chen W. Upregulation of the long noncoding RNA FOXD2-AS1 promotes carcinogenesis by epigenetically silencing EphB3 through EZH2 and LSD1, and predicts poor prognosis in gastric cancer. Oncogene. 2018;37(36):5020-36.

111. Hou M, Zhan Y, Sheng X, Liu X, Fu Q, Li S, Liang N, Li F, Li C, Sui C, et al. LncRNA FOXD2-AS1 Functions as a Competing Endogenous RNA to Regulate TERT Expression by Sponging miR-7-5p in Thyroid Cancer. J Cell Biochem. 2019;10:207.

112. Meyers-Needham M, Ponnusamy S, Gencer S, Jiang W, Thomas RJ, Senkal CE, Ogretmen B. Concerted functions of HDAC1 and microRNA574-5p repress alternatively spliced ceramide synthase 1 expression in human cancer cells. EMBO Mol Med. 2012;4(2):::78-92.

113. Ji S, Ye G, Zhang J, Wang L, Wang T, Wang Z, Zhang T, Wang G, Guo Z, Luo Y. miR-574-5p negatively regulates Qki6/7 to impact $\beta$-catenin/ Wnt signalling and the development of colorectal cancer. Gut. 2013;62(5):716-26.

114. Zhang X-Q, Sun S, Lam K-F, Kiang KM-Y, Pu JK-S, Ho AS-W, Lui W-M, Fung C-F, Wong T-S, Leung GK-K. A long non-coding RNA signature in glioblastoma multiforme predicts survival. Neurobiol Dis. 2013;58:123-31.

115. Zhai H-Y, Sui M-H, Yu X, Qu Z, Hu J-C, Sun H-Q, Zheng H-T, Zhou K, Jiang L-X. Overexpression of long non-coding RNA TUG1 promotes colon cancer progression. Med Sci Monit. 2016;22:3281.

\section{Publisher's Note}

Springer Nature remains neutral with regard to jurisdictional claims in published maps and institutional affiliations.
Ready to submit your research? Choose BMC and benefit from:

- fast, convenient online submission

- thorough peer review by experienced researchers in your field

- rapid publication on acceptance

- support for research data, including large and complex data types

- gold Open Access which fosters wider collaboration and increased citations

- maximum visibility for your research: over $100 \mathrm{M}$ website views per year

At BMC, research is always in progress.

Learn more biomedcentral.com/submissions 